\title{
CHARACTERISTICS OF FISH CRACKERS BASED ON TYPES OF FISH AND DIFFERENT TYPES OF STARCH
}

\author{
Dede Zainal Arief \\ Yusep Ikrawan \\ Faradilla Noor Rizqia \\ Department of Food Technology, Faculty of Engineering, Pasundan University, Dr.Setiabudi Street No 93, Bandung, \\ 40153, Indonesia \\ E-mail : dedezainalarief17@unpas.ac.id
}

\begin{abstract}
The purpose of this research is to produce fish crackers from different types of fish, namely catfish and patin fish as well as different types of starch and know the characteristics of a good fish crackers. The benefit that can be expected from this research was to utilize catfish and patin fish abundant potency and add economic value. The method of this research was divided into two stages, namely the first stage is the stage which determines the range of the comparison with the fish flour, determine the type of fish and determine the type of flour used by using the hedonik method of organoleptic parameters. On the second stage has a purpose and that is to analyze chemical and physical fish crackers by comparison. The data were analyzed using the method of experiment results simple linear variable $(\mathrm{x})$ increase in comparison of fish and flour (part). The free variable (y) consists of the response of the color, flavor, aroma, texture, volume and the development levels of crispness. The type of fish and the type of starch correlated against all response organoleptic, except the catfish and tapioca flour was not correlated against sense, catfish and cornmeal were not correlated against the texture of the fish, and catfish and sago flour not correlated against scent. The highest correlation is indicated by the sample composition of the cornmeal and catfish fish total value index by 17 of the total value of the correlation coefficient in classification. The sample was selected based on organoleptic level consumer favorite is with the composition of samples catfish and tapioca flour with a 1:1 comparison (111). Based on the results of the chemical analysis of protein obtained $24,38 \%$, fat content of $1.6 \%$, levels of starch of $44.69 \%$ and water content of $5.5 \%$. Physical analysis of the parameter and the mobilising of the volume development of IE of $146.43 \%$ and the level of crispness that is of $0.56 \mathrm{~mm} / \mathrm{s} / 50 \mathrm{gram}$.
\end{abstract}

Keyword: Crackers, Fish, Starch

\section{Introduction}

Crackers is a type of snack that has long been known by most people of Indonesia. Crackers have their own place for the lovers. Kinds of crackers vary in every area in Indonesia, for example, crackers kemplang in Bangka, crackers Palembang which is certainly in Palembang. Crackers are a snack or a complementary food that is very liked by everyone from children to adults. Along with the development of the era of crackers also experienced a change, from the first crackers only delivered directly by the factory to the seller until now crackers that have started various kinds of forms and flavor variants.

Crackers can be consumed as a food interlude or as a variation in side dishes. As a commodity merchandise crackers included into the type of industrial products that have good potential. (Koswara, 2009).

The biggest component of crackers is starch so that crackers have a low protein content. Need to do business diversification of food (food diversification) aimed at increasing the nutrient content of crackers, especially protein content.
The raw materials used should contain sufficiently high starch and experience volume development during frying, suppose that tapioca flour, sago flour, wheat flour, or rice flour. But the most widely used is tapioca flour derived from cassava. Increased consumption of crackers in the community resulted in the production of tapioca flour is increasing as well, resulting in the price of tapioca flour that gradually rose.

Given the increased use and price of tapioca starch, this study provides an alternative to using sago flour and maize flour. Starch is the most component in raw sago cracker that is $85.56 \%$ at $9.43 \%$ moist water content, because the sago flour used has high starch content. Sago starch has a very high carbohydrate content of about $98 \%$ dry weight. Sago starch granules have a high expansion power of $97 \%$. This is required at the development stage of crackers. Sago flour was a potential raw material of high expansion crackers that is 97\% (Koswara, 2009). While maize is also one of the starch that has a high enough starch content. Maize powder is obtained from corn starch, because of the 
abundance of cornstarch stock, maize starch is also selected as alternative material for fish cracker making.

In terms of nutrition, when observed the composition, crackers can be a source of calories derived from starch (and fat when it has been fried), as well as protein sources (if fish and shrimp are actually added). From the results of existing peneletian analysis it was found that crude protein crack protein content varied from 0.97 to $11.04 \%$ wet weight (with varying water content from 9.91 to $14 \%$ ). While the levels of the pills vary from 10.27 to $26.37 \%$ wet weight (Koswara, 2009).

Fish is produced by nature and it obtained in abundance. One of the processed food from fish is fish crackers. Dried food products with fish raw materials mixed with tapioca flour is very popular community.

In this study, selected dumbo catfish (Clarias gariepinus) and patin (Pangasius sp) as one of the complement or filler in fish crackers. In addition to one as a flavor enhancer to crackers, catfish and patin are also selected to increase the choice of variety and nutritional value.

Dumbo catfish (Clarias gariepinus) is one type of fish that is now widely cultivated by fish farmers. Catfish contains moisture content 78,5 gr, calories 90 gr, protein $18,7 \mathrm{gr}$, fat $1,1 \mathrm{gr}$, Calcium (Ca) $15 \mathrm{gr}$, Phospor (P) 260 gr, Iron (Fe) 2 gr, Sodium 150 gr, Thiamin 0.10 gr, Riboflavin 0.05 gr, Niashin 2.0 gr per 100 gram. So the catfish contains high protein and bone strengthening substances $(\mathrm{Ca})$ is good for children's food under five. In addition, catfish also contains other minerals that are also important for the health of the body (Djatmiko Hertami, 1996).

Patin fish (Pangasius sp) is a commodity of fishery cultivation whose market is quite promising. Catfish fish market is still dominated by Vietnam with exports in the form of fillets and processed products based surimi. Catfish can be processed traditionally and modern so as to increase the added value of catfish. Catfish meat has a high protein content advantage over other fresh fish, so catfish can be substituted with various protein sources in various foods or snacks (Wahyuningsih, 2011).

Based on the above data the authors want to take advantage of fish species namely catfish and catfish with different types of starch that is tapioca, sago and maizena are processed into crackers. To know the existence of different characteristic of some type of fish and starch type hence writer interested to conduct research with title Characteristic of Fish Cracker from Various Kind of Fish and Type of Starch.

\section{Methods}

The ingredients used in the manufacture of fish crackers are dumbo catfish (Clarias gariepinus) and local catfish (Pangasius sp) obtained from Citimun village, Cimalaka subdistrict, Sumedang district, tapioca, sago, maize, salt, sugar, garlic, water, wheat flour and baking soda.

The ingredients used for the analysis are $\mathrm{HgO}$, $\mathrm{K}_{2} \mathrm{SO}_{4}, \mathrm{H}_{2} \mathrm{SO}_{4}$, boiling stones, aquades, $\mathrm{H}_{3} \mathrm{BO}_{3}, 0.2 \%$ methyl red, $0.2 \%$ methyl blue, $0.02 \mathrm{~N} \mathrm{HCl}$, petroleum benzene, $3 \% \mathrm{HCl}, \mathrm{NaOH} 40 \%$, Luff Schoorl solution, Potassium Iodide $15 \%, \mathrm{H}_{2} \mathrm{SO}_{4} 25 \%, \mathrm{Na}_{2} \mathrm{~S}_{2} \mathrm{O}_{3} 0.1 \mathrm{~N}$, amylum $1 \%$, quartz sand.

The tools used in the research are analytic balance scales, basins, knives, cutting board, food processor, and tunnel drier. The tools used for the analysis are erlenmeyer flask, burette, filter paper, soxhlet extraction tool, quartz sand, oven and desiccator. The tools used to identify microscopic characteristics of fish crackers ie JEOL-JSM-6510LV type JEOL-Scanning Electronic Microscope Instrument FMIPA ITB and Phenetrometer at BALITSA, Lembang.

The research is divided into two stages including research phase I and phase II. In the research of making crackers conducted aims to:

1. Making crackers without the use of developer materials (baking soda).

2. Determining the ratio range of flour to fish.

3. Determining the type of fish used

4. Determine the type of flour used.

The overall sample to be studied can be seen in table 1 . In table 1 is different for each type of fish, the type of fish used in this study is catfish and catfish. And the type of flour used in this study is tapioca starch, cornstarch and sago flour. All samples tested in the study amounted to 108 products. The parameters used in stage I are using organoleptic test on color, fish flavor, crispy texture and typical fish aroma. The hedonic test is based on panelist's favorite level of 15 people, against fish crackers. The comparison table between flour and fish is as follows :

Table 1. Comparison Between Flour and Fish

\begin{tabular}{|c|c|c|c|}
\hline $\begin{array}{c}\text { Number } \\
\text { of sample }\end{array}$ & Ratio & Flour & Fish \\
\hline 1. & $1: 1$ & 34.0 & 34.0 \\
\hline 2. & $1: 2$ & 22.7 & 45.3 \\
\hline 3. & $1: 3$ & 17.0 & 51.0 \\
\hline 4. & $1: 4$ & 13.6 & 54.4 \\
\hline 5. & $1: 5$ & 11.3 & 56.7 \\
\hline 6. & $1: 6$ & 9.70 & 58.3 \\
\hline 7. & $1: 7$ & 8.50 & 59.5 \\
\hline 8. & $1: 8$ & 7.60 & 60.4 \\
\hline 9. & $1: 9$ & 6.80 & 61.2 \\
\hline 10. & $9: 1$ & 61.2 & 6.80 \\
\hline 11. & $8: 1$ & 60.4 & 7.60 \\
\hline 12. & $7: 1$ & 59.5 & 8.50 \\
\hline 13. & $6: 1$ & 58.3 & 9.70 \\
\hline 14. & $5: 1$ & 56.7 & 11.3 \\
\hline 15. & $4: 1$ & 54.4 & 13.6 \\
\hline 16. & $3: 1$ & 51.0 & 17.0 \\
\hline 17. & $2: 1$ & 45.3 & 22.7 \\
\hline
\end{tabular}


In further research or phase II has the objective of analyzing chemically and physically fish cracker with the selected ratio of organoleptic results data in the first phase of research that matches the characteristics of crackers favored by consumers.

\section{Result and Discussion}

Table 2. Comparison Between Flour and Fish Which Produce Crackers

\begin{tabular}{|c|c|c|c|c|}
\hline Number of sample & Ratio & Flour & Fish & Explanation \\
\hline 1. & $1: 1$ & 34.0 & 34.0 & Formed dough, tasted fish \\
\hline 2. & $1: 2$ & 22.7 & 45.3 & Formed dough, tasted fish \\
\hline 3. & $1: 3$ & 17.0 & 51.0 & Formed dough, tasted fish \\
\hline 4. & $1: 4$ & 13.6 & 54.4 & Formed dough, tasted fish \\
\hline 5. & $1: 5$ & 11.3 & 56.7 & Formed dough, tasted fish \\
\hline 6. & $1: 6$ & 9.70 & 58.3 & Formed dough, not tasted fish \\
\hline 7. & $1: 7$ & 8.50 & 59.5 & Formed dough, not tasted fish \\
\hline 8. & $1: 8$ & 7.60 & 60.4 & Formed dough, not tasted fish \\
\hline 9. & $1: 9$ & 6.80 & 61.2 & Formed dough, not tasted fish \\
\hline 10. & $9: 1$ & 61.2 & 6.80 & Not formed dough \\
\hline 11. & $8: 1$ & 60.4 & 7.60 & Not formed dough \\
\hline 12. & $7: 1$ & 59.5 & 8.50 & Not formed dough \\
\hline 13. & $6: 1$ & 58.3 & 9.70 & Not formed dough \\
\hline 14. & $5: 1$ & 56.7 & 11.3 & Not formed dough \\
\hline 15. & $4: 1$ & 54.4 & 13.6 & Formed dough, tasted fish \\
\hline 16. & $3: 1$ & 51.0 & 17.0 & 22.7 \\
\hline 17. & $2: 1$ & 45.3 & 2.3 & 0.6677 and \\
\hline
\end{tabular}

Thus a testable sample comprising only fish meal versus 1: 1, 1:2, 1:3,1:4, 1: 5 and 2: 1 .

From the test results of the development of crackers without using baking soda, produced a cracker that did not expand. With these results then on each dough crackers tested added baking soda.

2. Organoleptic Result Based On Linear Regression Catfish (Pangasius sp.) and Maize Flour

a. Color Response

From the results of a study conducted a comparison of catfish with tapioca flour that produces crackers is 1: 1 to $1: 5$ and 2: 1 . In accordance with organoleptic test that has been done according to consumer's favorite response with hedonic method, it can be seen the effect of correlation value with the increase of fish addition to the flour on the curve as follows:

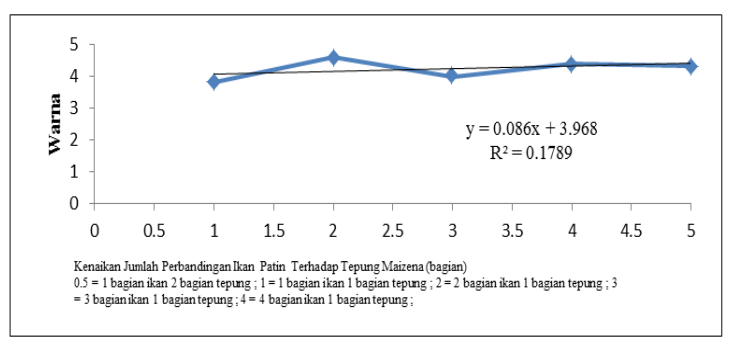

Figure 1. Linear Regression of Organoleptic Test against Color of Fish Chips of Patin and Maizena Flour

Based on the curve in figure (1) above shows a linear relationship with the average that is $y=0.086 \mathrm{x}+$ 3.968 with the value of correlation coefficient (r) is

\section{Comparison of Fish and Flour}

Range Comparison of Fish and Flour From the results of the research, the comparison of flour to fish that produce crackers is 1: 1 up to $1: 5$ and 2: 1 . Sample 3: 1 to 9: 1 produces a cracker that does not taste fish at all, while 1: 6 to 1: 9 can not produce a printable cracker dough.

0.6677 and the value of coefficient of determination $\left(\mathrm{R}^{2}\right)$ is 0.1789 indicates that between the increase in the ratio of catfish to starch maize with average organoleptic yield on color has enough correlation, but can be seen the value of correlation coefficient (r) with positive sign indicating the existence of correlation or direct linear relationship but low value, hence can be concluded that enough color

b. Taste Response

From the results of a study conducted a comparison of catfish with cornstarch that produce crackers is $1: 1$ to 1 : 5 and 2: 1. In accordance with organoleptic test that has been done according to consumer's favorite response with hedonic method, can be seen the effect of correlation value with increase of fish addition to the flour on the curve as follows:

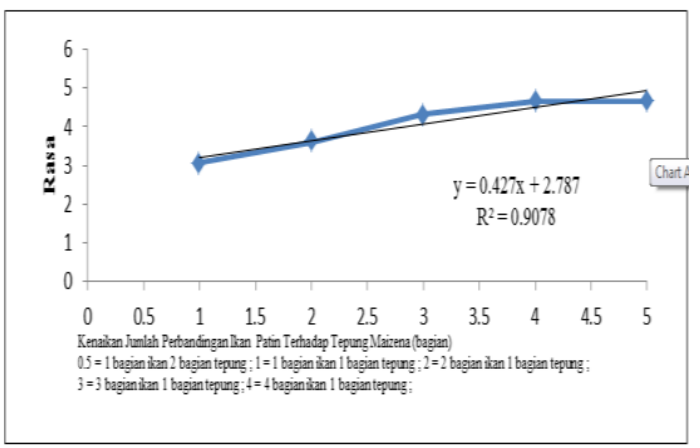

Figure 2. Linear Regression of Organoleptic Tests on Pancake Flavor of Patin Fish and Maizena Flour 
Based on the curve in figure (2) above shows a linear relationship with the average that is $y=0.427 x+$ 2.787 with the value of correlation coefficient $(r)$ is 0.9685 and the coefficient of determination $\left(\mathrm{R}^{2}\right)$ is 0.9078 indicates that between the increase of the ratio of catfish to the flour maize with the average of organoleptic results on the sense of having a very high correlation, but can be seen the value of correlation coefficient (r) with a positive sign indicating a perfect correlation or direct linear relationship, it can be concluded that the sense is directly affect the level of consumer preference.

\section{c. Aroma Response}

From the results of a study conducted a comparison of catfish with cornstarch that produce crackers is 1: 1 to $1: 5$ and 2: 1 . In accordance with organoleptic test that has been done according to consumer's favorite response with hedonic method, it can be seen the effect of correlation value with the increase of fish addition to the flour on the curve as follows:

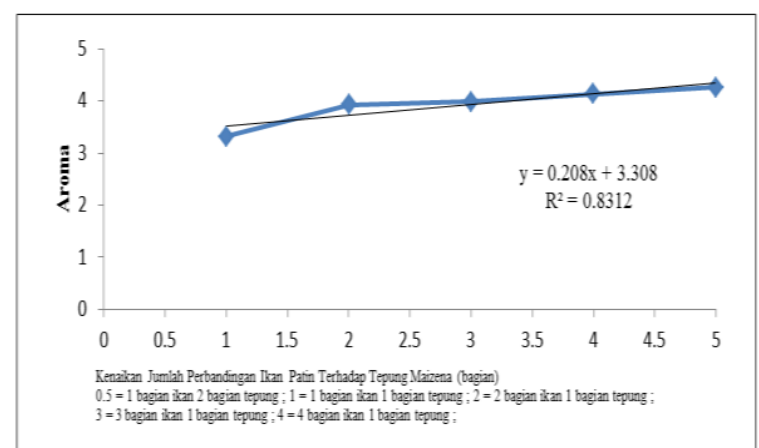

Figure 3. Linear Regression of Organoleptic Tests on the Aroma of Catfish Crackers and Maize Flour

Based on the curve in figure (3) above shows the linear relationship with the average that is $y=0.208 x+$ 3.308 with the value of correlation coefficient $(r)$ is 0.8663 and the coefficient of determination $\left(\mathrm{R}^{2}\right)$ is 0.8312 indicates that between the increase of catfish comparison to the flour maize with average organoleptic yield on aroma has a high correlation, can be seen with the value of correlation coefficient (r) with positive sign indicating perfect correlation or direct linear relationship, it can be concluded that the aroma directly affects the level of consumer preference.

\section{d. Texture Response}

From the results of a study conducted a comparison of catfish with cornstarch that produce crackers is 1: 1 to $1: 5$ and 2: 1 . In accordance with organoleptic test that has been done according to consumer's favorite response with hedonic method, it can be seen the effect of correlation value with the increase of fish addition to the flour on the curve as follows:

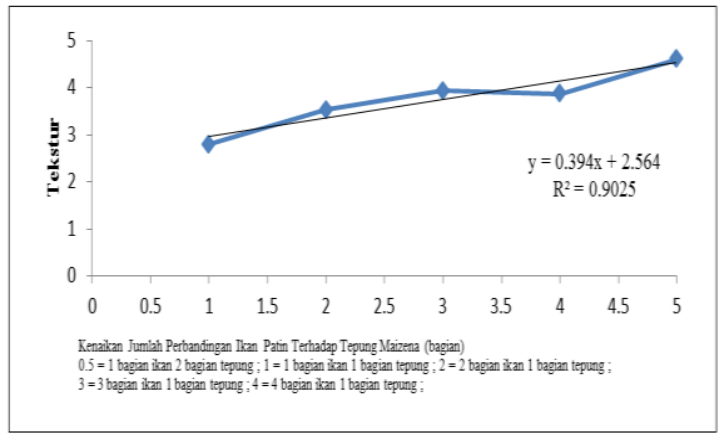

Figure 4. Linear Regression of Organoleptic Tests on

Texture of Fish Crackers and Maize Flour

Based on the curve in figure (4) above shows a linear relationship with the average that is $y=0.394 x+$ 2.564 with the value of correlation coefficient $(r)$ is 0.9456 and the coefficient of determination $\left(\mathrm{R}^{2}\right)$ is 0.9025 indicates that between the increase of the ratio of catfish to the flour maize with the average of organoleptic results on texture has a very correlation, can be seen with the value of correlation coefficient (r) with a positive sign indicating perfect correlation or direct linear relationship, it can be concluded that the texture is directly affect the level of consumer preference.

3. Organoleptic Results Based on Consumer Favourite of Patin Fish and Tapioca

a. Color Response

From the results of a study conducted a comparison of catfish with tapioca flour that produces crackers is 1: 1 to $1: 5$ and 2: 1 . In accordance with organoleptic test that has been done according to consumer's favorite response with hedonic method, it can be seen the effect of correlation value with the increase of fish addition to the flour on the curve as follows:

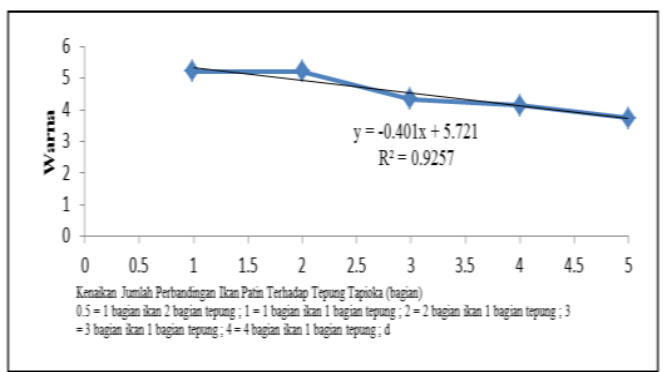

Figure 5. Linear Regression Organoleptic Tests Against the Texture of Catfish Crackers and Tapioca.

Based on the curve in figure (5) above shows a linear relationship with the average of $y=-0.401 x+$ 5.721 with the value of correlation coefficient $(r)$ is 0.937 and the value of determination coefficient $\left(R^{2}\right)$ is 0.9257 indicates that between the increase in the ratio of flour and fish with an average of organoleptic results on color has a high correlation, it can be concluded that the color affects the level of consumer preference. The value of the correlation coefficient $(r)$ were negative 
indicates that the relationship between the average results of organoleptic color with the addition of the increase in fish as a perfect correlation or perfect linear relationship is not direct.

\section{b. Sense Response}

From the results of a study conducted a comparison of catfish with tapioca flour that produces crackers is $1: 1$ to $1: 5$ and 2: 1 . In accordance with organoleptic test that has been done according to consumer's favorite response with hedonic method, it can be seen the effect of correlation value with the increase of fish addition to the flour on the curve as follows:

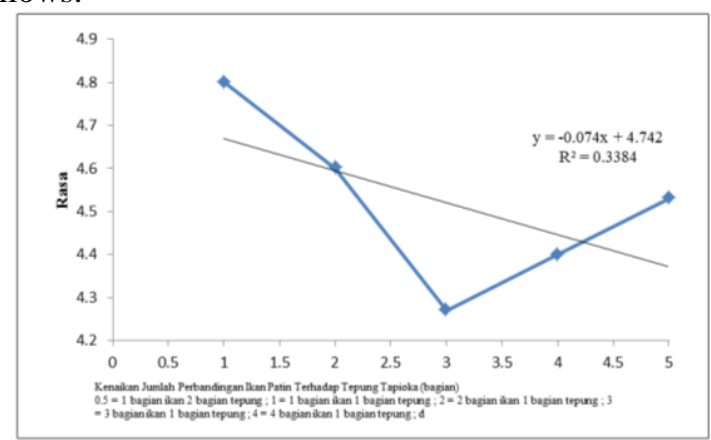

Figure 6. Linear Regression Test Texture Appearance Against Crackers Catfish and Tapioca

Based on the curve in figure (6) above shows a linear relationship with the average of $y=-0.074 x+$ 4.742 with the value of correlation coefficient (r) is 0.712 and the value of determination coefficient $\left(R^{2}\right)$ is 0.3384 indicates that between the increase in the ratio of flour and fish with an average of organoleptic results on a sense of having a fairly low correlation, so it can be concluded that the smell is not very influential on the level of consumer preference.

\section{c. Aroma Response}

From the results of a study conducted a comparison of catfish with tapioca flour that produces crackers is 1: 1 to 1: 5 and 2: 1 . In accordance with organoleptic test that has been done according to consumer's favorite response with hedonic method, it can be seen the effect of correlation value with the increase of fish addition to the flour on the curve as follows:

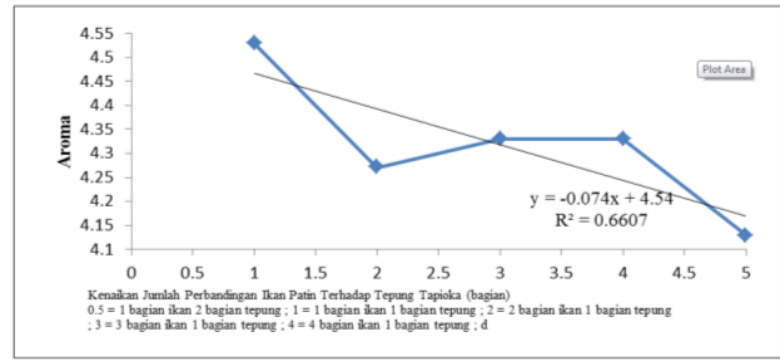

Figure 7. Linear Regression Test Texture Appearance Against Crackers catfish and Tapioca

Based on the curve in figure (7) above shows a linear relationship with the average of $y=-0.074 x+$ 4.54 with the value of correlation coefficient $(r)$ is 0.873 and the value of determination coefficient $\left(R^{2}\right)$ is 0.6607 indicates that between the increase in the ratio of flour and fish with an average yield of organoleptic to aroma has a high correlation.

\section{d. Texture Response}

From the results of a study conducted a comparison of catfish with tapioca flour that produces crackers is 1: 1 to $1: 5$ and 2: 1 . In accordance with organoleptic test that has been done according to consumer's favorite response with hedonic method, it can be seen the effect of correlation value with the increase of fish addition to the flour on the curve as follows :

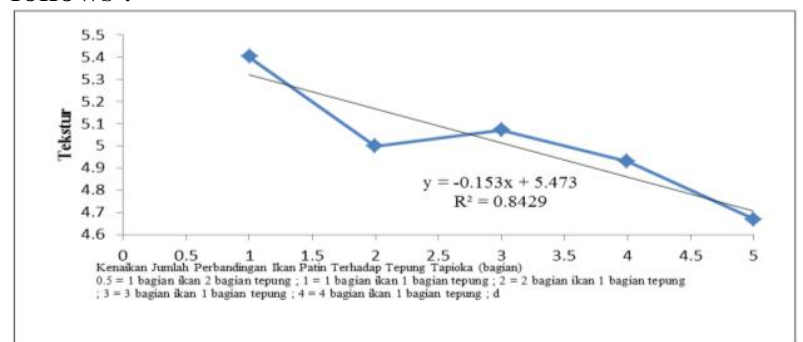

Figure 8. Regression Test Texture Appearance Against Crackers catfish and Tapioca

Based on the curves in the figure (8) above shows a linear relationship with the average that is $y=-$ $0.153 x+5473$ with the value of the correlation coefficient (r) is -0.917 , and the coefficient of determination $\left(\mathrm{R}^{2}\right)$ was 0.8429 indicates that a comparison between the increase in flour and fish with the average results of organoleptic aromas have a high correlation, so that the texture influence consumer preference level against crackers.

\section{Final Corelation Results}

Based on the correlation test of all samples tested then there is a sample category based on correlation. The results can be seen in the table as follows: 
Table 2. Results Correlation Simple Linear Regression Methods

\begin{tabular}{|c|c|c|c|c|}
\hline Parameter uji & Komposisi & Tingkat Korelasi & Indeks & Total \\
\hline Colour & \multirow[t]{4}{*}{ Catfish and Tapioca } & High correlation $(0,71-0,90)$ & 4 & \multirow[t]{4}{*}{10} \\
\hline Sense & & Not correlated $(0,0-0,20)$ & 1 & \\
\hline Aroma & & Low correlation $(0,21-0,40)$ & 2 & \\
\hline Texture & & Enough correlation $(0,4-0,70)$ & 3 & \\
\hline Colour & \multirow[t]{4}{*}{ Catfish and Maize } & Enough correlation $(0,4-0,70)$ & 3 & \multirow[t]{4}{*}{12} \\
\hline Sense & & High correlation $(0,71-0,90)$ & 4 & \\
\hline Aroma & & High correlation $(0,71-0,90)$ & 4 & \\
\hline Texture & & Not correlated $(0,0-0,20)$ & 1 & \\
\hline Colour & \multirow[t]{4}{*}{ Catfish and Sago } & High correlation $(0,71-0,90)$ & 4 & \multirow[t]{4}{*}{14} \\
\hline Sense & & High correlation $(0,71-0,90)$ & 4 & \\
\hline Aroma & & Low correlation $(0,21-0,40)$ & 2 & \\
\hline Texture & & High correlation $(0,71-0,90)$ & 4 & \\
\hline Colour & \multirow[t]{4}{*}{ Catfish (Pangasius sp.) and Tapioca } & High correlation $(0,71-0,90)$ & 4 & \multirow[t]{4}{*}{14} \\
\hline Sense & & Low correlation $(0,21-0,40)$ & 2 & \\
\hline Aroma & & High correlation $(0,71-0,90)$ & 4 & \\
\hline Texture & & High correlation $(0,71-0,90)$ & 4 & \\
\hline Colour & \multirow[t]{4}{*}{ Catfish (Pangasius sp.) and Maize } & Enough correlation $(0,4-0,70)$ & 3 & \multirow[t]{4}{*}{17} \\
\hline Sense & & Very high correlation $(0,91-1,0)$ & 5 & \\
\hline Aroma & & High correlation $(0,71-0,90)$ & 4 & \\
\hline Texture & & Very high correlation $(0,91-1,0)$ & 5 & \\
\hline Colour & \multirow[t]{4}{*}{ Catfish (Pangasius sp.) and Sago } & High correlation $(0,71-0,90)$ & 4 & \multirow[t]{4}{*}{11} \\
\hline Sense & & High correlation $(0,71-0,90)$ & 4 & \\
\hline Aroma & & Not correlated $(0,0-0,20)$ & 1 & \\
\hline Texture & & Low correlation $(0,21-0,40)$ & 2 & \\
\hline
\end{tabular}

Selected Sample Based on Organoleptic Test Results

Table 4. Results of selected organoleptic test against fish species and starch types

\begin{tabular}{|l|l|r|}
\hline \multicolumn{1}{|c|}{ Kode sampel } & \multicolumn{1}{|c|}{$\begin{array}{c}\text { Parameter } \\
\text { Uji }\end{array}$} & \multicolumn{1}{c|}{$\begin{array}{c}\text { Rata- } \\
\text { rata }\end{array}$} \\
\hline $\begin{array}{l}\text { 111 (1:1) Patin fish and } \\
\text { Tapioca }\end{array}$ & Color & 5.20 \\
\cline { 2 - 3 } & Sense & 4.80 \\
\cline { 2 - 3 } & Aroma & 4.53 \\
\cline { 2 - 3 } & Texture & 5.40 \\
\hline Score & & $\mathbf{1 9 . 9 3}$ \\
\hline 523 (1:5) Patin fish and & Color & 4.33 \\
\cline { 2 - 3 } & Sense & 4.67 \\
\cline { 2 - 3 } & Aroma & 4.27 \\
\cline { 2 - 3 } & Texture & 4.60 \\
\hline \multirow{2}{*}{ Score } & & $\mathbf{1 7 . 8 7}$ \\
\hline \multirow{2}{*}{ 178 (1:1) Patin fish and Sago } & Color & 5.07 \\
\cline { 2 - 3 } & Sense & 5.07 \\
\cline { 2 - 3 } & Aroma & 4.53 \\
\cline { 2 - 3 } & Texture & 5.00 \\
\hline \multirow{2}{*}{ Score } & $\mathbf{1 9 . 6 7}$ \\
\hline
\end{tabular}

5. Physical Chemical Analysis of Selected Samples a. Developt volume

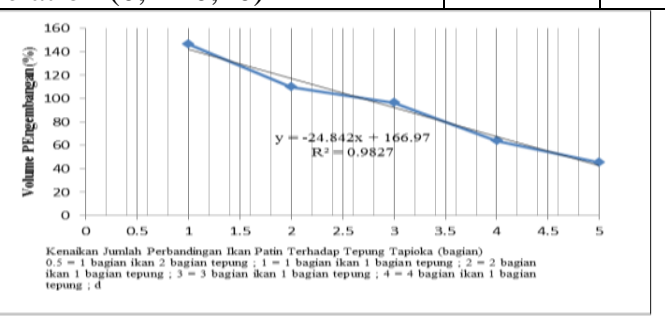

Figure 9. Curve of crackers developt volume on each increase in the number of fish added

Based on the curve in Figure 9, shows a linear relationship with the average that is $\mathrm{y}=-24.842 \mathrm{x}+$ 166.97 with a correlation coefficient (r) was 0.9792 and the coefficient of determination ( $\mathrm{R}^{2}$ ) was 0.9589 indicates that a comparison between the increase in flour and fish with volume development has a very high correlation.

A positive correlation coefficient (r) indicates that the relationship between the increase in the ratio of flour and fish to the development volume as a perfect correlation directly with a positive slope is also indicated by a positive slope value of $3,8001 \mathrm{x}$ means that more flour is added the higher the value of the development of catfish crackers.

It cracker with 2: 1 ratio (616), while the 1: 1 (111) cracker is the second highest value. While the cracker with a ratio of 1: 5 represents the lowest development value. it can be concluded that the fillers are added then the fish crackers expands.
According
Zulfahmi
(2014), in

Kusumaningrum (2011) states that the difference in 
flower power directing that the more the content of amylopectin in the fish crackers skembangnya power will be even greater. This is because the amylopectin building is less compact and less restricts the development of mass volume before frying. Amylopectin content derived from tapioca flour, therefore, the greater the content of tapioca flour in fish crackers cause the greater the power of flowers.

Cracker's power will decrease if the percentage of flour content is more than filler (shrimp, fish, etc). In order to obtain better cracker power, the cracker dough should be in the proportion of flour with a balanced filler (Soemarmo, 2009)

\section{The level of crispness}

Hasil yang didapatkan dari analisis kadar protein bahan baku dapat dilihat pada Tabel 1 .

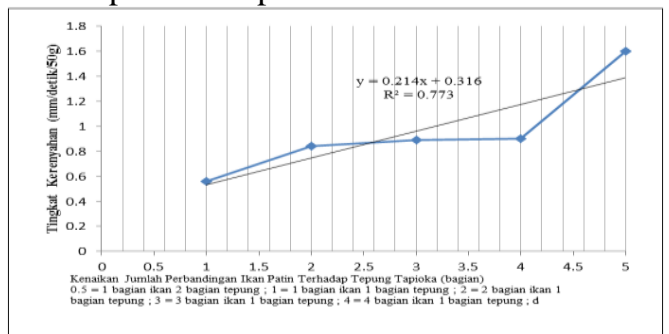

Figure 10. Level of crispy crackers On Any Increase in Number of Big Fish Added

Based on the curves in the figure (30) above shows a linear relationship with the average that is $\mathrm{y}=$ $0.214 \mathrm{x}+0316$ with the value of the correlation coefficient (r) was 0.8135 and the coefficient of determination $\left(\mathrm{R}^{2}\right)$ is 0773 indicates that the increase in ratio of flour and fish the level of crispness has a high correlation.

Figure 11. Scanning Electron Microscope Fish Cracker with Tapioca Starch

\begin{tabular}{|c|c|c|}
\hline \multirow[t]{2}{*}{ Kode Sampel } & \multicolumn{2}{|c|}{ Kerupuk Ikan Patin } \\
\hline & $100 \mu \mathrm{m}$ & $500 \mu \mathrm{m}$ \\
\hline $1: 1(111)$ & & \\
\hline
\end{tabular}

In the picture above, we can see the results based on magnification of 100x and 500x. Figure 11 shows the surface of fish crackers with a ratio of $1: 1$ starch there was a starch development, due to gelatinization, where swelling of irreversible starch granules, then trapped by the drying process. When frying, the crackers will expanded due to the temperature rise. The morphology of crackers development was saw from the crosssectional area of the SEM image. The internal structure of crackers development was influenced by the type of
The positive correlation coefficient (r) indicates that the relationship between the increase in the ratio of flour and fish to the level of crispness as a high correlation but directly with a positive slope is also indicated by a positive slope value of $-0.214 x$.

Measurement of the level of crispness using phenetrometer has an assessment of the harder material measured, the lower the value of crispness. Conversely the soft material that is measured, the higher the value of crispness or texture. It can be seen from the curve above that the fewer fish added, the lower the crunchiness. Crackers with a ratio of 2: 1 (616) and 1: 1 (111) are crackers with a good crispness of $0.56 \mathrm{~mm} /$ $\mathrm{sec} / 50 \mathrm{~g}$ and $0.79 \mathrm{~mm} / \mathrm{sec} / 50 \mathrm{~g}$. While the cracker with a ratio of 1: 5 (255) is the cracker with the lowest level of crispness $1.60 \mathrm{~mm} / \mathrm{sec} / 50 \mathrm{~g}$.

The degree of crispness is usually related to the volume of development. According to Zulfahmi (2014), the protein serves to thicken the amylopectin granules, so the more protein the harder the crackers will become. This result is almost the same as that of Huda et. al. (2009) about fish crackers with the addition of fish meat dori that is in the range $1312,34-2366,49 \mathrm{~N} / \mathrm{cm} 2$. This is in accordance with the opinion of Koswara (2009) in Mas'ud and Veni (2014), that in addition to the high levels of amylopectin, the crunchiness of crackers is also affected by the thickness of the crackers when sliced. Should in slicing fish crackers using a special tool cutters crackers, so that the thickness of 2-3 mm, it aims to get a uniform and crunchy crackers pieces when fried.

\section{Scanning Electron Microscope}

fish. In the above samples, a cellular porous structre is shown. During frying, the evaporation of water in the rapid crackers causes the product to expand.

According to Cheow et al (1999) in Kaewmanee et al (2015), found that in the development of microstructure crackers tend to have protein aggregates. This will inhibit the expansion of the dough when fried, leading to a solid structure Crackers. The texture of crackers is influenced by the distribution of pore size and wall thickness of the pores. Saeleaw and Schleining 
(2011), stated that many crispy foods would be difficult to chew, if they did not have pores. Noorakmar et al (2012), found the ratio of fish, tapioca flour, and sweet potato, in flour mixture, affect the internal structure of snacks. Large air cells are obtained from extruded fish crackers with low fish and high flour, while smaller air cells obtained as fish content increase.

\section{Chemist Analysis}

a. Protein Contentss

Based on the analysis of protein content with kjedahl method, the protein content of catfish cracker with ratio 1: 1 (111) is $24,38 \%$. When compared with the existing quality requirements on SNI for crackers that have a maximum protein source is $5 \%$. Factors that cause greater levels of protein found in catfish crackers is due to the addition of other ingredients such as eggs that have a high protein content of 12.8 grams per 100 grams of ingredients and protein content of tapioca starch that is equal to 1.1 grams per 100 grams of material. In addition, the content of potein found in catfish meat also affect the results of the analysis. According to Orban et al (2008) the protein content of catfish is about $17 \%$ or $12.6-15.6 \%$ bb per 100 grams.

\section{b. Fat Contents}

Based on the analysis of the fat content by soxhlet method derived fats obtained from crackers catfish with a ratio of 1: 1 (111) that is equal to $1.6 \%$. According Koswara (2009), fat content in fish crackers ranged from $1.40 \%-12.10 \%$. Fat content in catfish crackers can be derived from the fat content of catfish is about $6.6 \%$ or $1.1-3 \%$ bb per 100 grams of material. The fat contained in catfish crackers is thought to derive mostly from catfish. According to Kochhar (1993) in Histiany (2005), this fat plays an important role to produce off-flavor, such as rancid odor, langu, fatty and fishy, so there is often a smell of soil and blood in catfish. The size of fatty catfish crackers affect the consumer acceptance, especially on the taste of crackers.

According to Suzuki (1981) in Istanti (2005), the higher the water content, the fat content will be lower. It can also be caused by less dull stirring during kneading, causing the dough was not homogeneous.

\section{c. Starch Contents}

Based on the analysis of starch content with the method of luff schoorl obtained the level of starch derived from catfish cracker with the ratio of 1: 1 (111) that is equal to $44,69 \%$. While carbohydrate levels in commercial crackers as in Huda's research, et al (2010) carbohydrate levels in commercial products are between $50 \%$ to $80 \%$, high carbohydrate content due to the type of flour used. Starch content on nutritional value of crackers varied between $10.27 \%$ to $23.67 \%$ wet weight (Koswara, 2009).

Starch is a carbohydrate compound composed by amylose molecules and amylopectin. According
Sudarmadji (1997), the number of amylose and amylopectin in the starch will affect the starch content contained in a material. Starch is the largest part of flour, can be used as a binder, thickening agent or as filler. The main function of starch in the manufacture of crackers is as the main material forming texture in the presence of starch gel.

\section{d. Water Contents}

Based on water content analysis with gravimetric method obtained from catfish cracker with ratio 1: 1 (111) that is equal to $5,5 \%$. When compared with the requirement of cracker quality in accordance with SNI that is $12 \%$, catfish crackers meet the criteria of good crackers, because seen from the volume of development, texture and age of good intersection.

The evaporation mechanism of water that affects the volume of development is when the water temperature increases, the average number of water molecules in the water molecule crowd decreases and the hydrogen bond breaks out and re-establishes rapidly. When water is heated even higher so that water molecules move so fast and water vapor pressure exceeds atmospheric pressure, some molecules can escape from the surface and look for gas. This gas will push the starch gel causing the crackers to expand (Winarno, 1992)

If the water content exceeds $12 \%$ will result in a less expansive development volume because the moisture that pushes the starch gel too much so that it can not get stuck will consequently get away with it. Crackers that have a water content of more than $12 \%$ have a texture characteristics are tough and short shelf life.

Water content in crackers is a very important parameter, because water content can affect the quality and capacity of the development of crackers. According to Wiriano (1984) in Juwita (2010), a certain level of moisture content of cracker product is required to produce vapor pressure in the frying process so that the gel can expand.

Factors that can affect the water content one of which is the process of steaming and drying. According to Tahir (1985) in Juwita (2010), in the process of steaming and drying, the pores of a material will be wide or enlarged so that water will evaporate and the remaining water in a food becomes less.

Based on the result of research, it can be concluded as follows:

1. Fish type and starch type correlated to all organoleptic responses, except catfish and tapioca flour not correlated to taste, catfish and cornstarch did not correlate to texture, and catfish and sago flour were not correlated to aroma.

2. The highest correlation is shown by the sample with the composition of catfish and cornstarch with the total index value of 17 of the total classification value of correlation coefficient, with the following equation $\mathrm{y}=$ 
$0.086 x+3.968$ with the value of $r=0.6677$ and the value of $\mathrm{R} 2=0.1789$ for the color response, $\mathrm{y}=0.427 \mathrm{x}$ +2.787 with the value of $r=0.9685$ and the value of $R 2$ $=0.9078$ for the taste response, $\mathrm{y}=0.208 \mathrm{x}+3.308$ with the value $r=0.8663$ and the value $R 2=0.8312$ for the aroma response, $\mathrm{y}=0.394 \mathrm{x}+2.564$ with the value $\mathrm{r}=$ 0.9456 and the value of $\mathrm{R} 2=0.9025$ for the texture response.

3. The selected sample based on organoleptic test of consumer's favorite level is the sample with the composition of catfish and tapioca flour with a ratio of 1: 1 (111).

4. Analysis result of catfish and tapioca flour with ratio 1: 1 (111) with some parameter of chemical analysis that is protein content equal to $24,38 \%$, fat content equal to $1,6 \%$, starch content equal to $44,69 \%$ and level water at $5.5 \%$. And from the parameters of physical analysis obtained the development volume of $146.43 \%$ and the crispness of $0.56 \mathrm{~mm} / \mathrm{sec} / 50$ gram.

\section{Bibliography}

1. Juwita, E. 2010. Pengaruh Jenis Bahan Pengisi dan Perbandingan Tepung Jagung Dengan Bahan Pengisi Terhadap Karakteristik Kerupuk Jagung (Zea mays L). Bandung : Skripsi, Program Studi Teknlogi Pangan, Fakultas Teknik. Universitas Pasundan.

2. Kaewmanee, T., Karrila, T.T. dan Benjakul, S. 2015. Effects of Fish Species on the Characteristics of Fish Cracker. International Food Reasearch Journal 22(5) : 2078-2087

3. Koswara, Sutrisno. 2009. Pengolahan Aneka Kerupuk. E-bookpangan.com. Diakses : 28/09/2015

4. Kusumaningrum, Indrati. 2009. Analisa Faktor Daya Kembang dan Daya Serap Kerupuk Rumput Laut pada Variasi Proporsi Rumput Laut (Eucheuma Cottonii). Samarinda : Jurnal Teknologi Pertanian, Universitas Mulawarman.

5. Lavlinesia. 1995. Kajian Beberapa Faktor Pengembangan Volumetrik dan Kerenyahan Kerupuk Ikan. Program Pasca Sarjana. Bogor : Institut Pertanian Bogor.

6. Mas'ud, I., Z. dan Veni, I. 2014. Pengaruh Proporsi Puree Kacang Tunggak(Vigna unguiculata (L) Walp) dan Teri Nasi (Stolephorus commersoni) terhadap Sifat Organoleptik Kerupuk. E-Journal Volume 03.

7. Siaw, C.L., A. Z. Indrus and S.Y. Yu. 1985. Intermediate Technology for Fish Craker (Keropok) Production. International Food Technology Journal 20 : 17-21.

8. Sudarmadji S., B. Haryono, dan Suhardi. 1997. Prosedur Analisa untuk Bahan Makanan dan Pertanian. Yogyakarta : Penerbit Liberty.

9. Tahir, S., 1985. Mempelajari Pembuatan dan Karakteristik Kerupuk dari Tepung Sagu. Ujung Pandang, Makassar : Skripsi. Fakultas Pertanian. Universitas Hasanudin
10. Winarno, F.G. 1996. Kimia Pangan dan Gizi. Jakarta : Penerbit PT. Gramedia Pusaka Utama.

11. Wiriano, H. 1984. Mekanisme dan Teknologi Pembuatan Kerupuk. Bogor : Balai Pengembangan Makanan, Departemen Perindustrian.

12.Zulfahmi, A.N., 2014. Pemanfaatan Ikan Tenggiri (Scomberomorus Commersoni) Dengan Konsentrasi Yang Berbeda Pada PEmbuatan Kerupuk Ikan. Semarang : Jurnal Pengolahan dan Bioteknologi Hasil Perikanan. Fakultas Perikanan dan Ilmu Kelautan. Universitas Diponegoro. 